\title{
Article \\ Genetic Diversity of Flavescence Dorée Phytoplasmas in Vineyards of Serbia: From the Widespread Occurrence of Autochthonous Map-M51 to the Emergence of Endemic Map-FD2 (Vectotype II) and New Map-FD3 (Vectotype III) Epidemic Genotypes
}

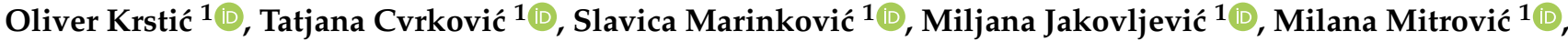 \\ Ivo Toševski ${ }^{1,2, *(\mathbb{D})}$ and Jelena Jović ${ }^{1, *(\mathbb{D})}$ \\ 1 Department of Plant Pests, Institute for Plant Protection and Environment, 11080 Zemun, Serbia; \\ oliverk13@yahoo.com (O.K.); tanjacvrkovic@yahoo.com (T.C.); slavicamar@gmail.com (S.M.); \\ miljka06@gmail.com (M.J.); milanadesancic@yahoo.co.uk (M.M.) \\ 2 CABI, 1 Rue des Grillons, 2800 Delemont, Switzerland \\ * Correspondence: tosevski_ivo@yahoo.com (I.T.); jovic_biolab@yahoo.com (J.J.)
}

check for updates

Citation: Krstić, O.; Cvrković, T.; Marinković, S.; Jakovljević, M.; Mitrović, M.; Toševski, I.; Jović, J. Genetic Diversity of Flavescence Dorée Phytoplasmas in Vineyards of Serbia: From the Widespread Occurrence of Autochthonous Map-M51 to the Emergence of Endemic Map-FD2 (Vectotype II) and New Map-FD3 (Vectotype III) Epidemic Genotypes. Agronomy 2022, 12, 448. https://doi.org/10.3390/ agronomy12020448

Academic Editor: Riccardo Velasco

Received: 31 December 2021

Accepted: 8 February 2022

Published: 11 February 2022

Publisher's Note: MDPI stays neutral with regard to jurisdictional claims in published maps and institutional affiliations.

Copyright: (C) 2022 by the authors. Licensee MDPI, Basel, Switzerland. This article is an open access article distributed under the terms and conditions of the Creative Commons Attribution (CC BY) license (https:// creativecommons.org/licenses/by/ $4.0 /)$.

\begin{abstract}
Flavescence dorée (FD) is a European quarantine disease of grapevine caused by FD phytoplasma (FDp) transmitted by the leafhopper of North American origin Scaphoideus titanus. The disease affects the most important viticultural regions of Europe and all wine-growing regions of Serbia. Unlike the insect vector, the pathogen is native to Europe and associated with several wild host plants among which alder trees as the main source of two out of three map genetic clusters of pathogen variants (Map-FD1 and FD2). Heretofore, the FDp epidemic in Serbian vineyards was thought to be monotypic, i.e., caused by the single genotype of the Map-FD3 cluster, M51, and correlated with clematis as the natural source plant. This study aimed to provide data on genetic diversity, through map and vmpA gene typing, and insights into ecological properties of epidemiological cycles driving the epidemic outbreaks of FD in Serbia today. Map genotyping of 270 grapevine isolates collected from 2017 to 2019 confirmed M51 as autochthonous genotype widespread in all wine producing regions of Serbia and the dominant FDp epidemic genotype in most of the districts (75\%, 202/270 isolates), except in north Serbia where multiple outbreaks of M12 Map-FD3 were recorded (54 isolates). Tree of heaven is reported as a new FDp plant reservoir for the Serbian vineyards, hosting the M51 genotype, along with clematis. An outbreak of a new endemic Map-FD3 genotype M144 was documented in grapevine samples from east Serbia (5 isolates), correlating with previous findings of the same genotype in clematis. In addition, single grapevine infections with five new Map-FD3 genotypes (M150-M154) were recorded in central Serbia, thus indicating high endemic potential for new outbreaks. The vmpA typing placed all Map-FD3 isolates into the VmpA-III cluster, i.e., Vectotype III. Finally, we found direct evidence that at least two FDp endemic genotypes, M89 and M148, of the Map-FD2/VmpA-II have escaped from alders and propagated in the grapevine-S. titanus pathosystem in Serbia (Vectotype II). Our findings confirm the high complexity of the FDp ecological cycle and provide evidence of a unique, autochthonous Balkan epidemiology sourced endemically.
\end{abstract}

Keywords: Ailanthus altissima; Alnus glutinosa; Clematis vitalba; epidemiology; FD phytoplasma; genetic diversity; grapevine yellows; map gene; Vitis vinifera; vmpA gene

\section{Introduction}

Flavescence dorée (FD) is a quarantine disease of grapevine caused by Flavescence dorée phytoplasma (FDp; taxonomic subgroups 16SrV-C and 16SrV-D) which has first emerged in the vineyards of south-western France in the 1950s [1]. The principle insectvector of FDp in European vineyards is a leafhopper of North American origin, Scaphoideus 
titanus, which spreads disease in epidemic manner due to its mostly ampelophagous feeding behavior, i.e., feeding primary on grapevines and hence transmitting disease from one grapevine to another [2,3]. The FD disease has a severe impact on productivity of affected vineyards, as well as on landscape management, which has caused significant economic losses in several European countries [3]. To date, FDp occurrence has been evidenced in viticultural regions of eleven European countries [4-6]; most recently found in Germany [6]. Based on genotyping of the epidemiologically informative house-keeping gene map [7,8], the FDp is comprised of variants within three genetic clusters namely MapFD1 (16SrV-C, reference strain FD70), FD2 (16SrV-C and 16SrV-D, reference strains FD92 and FD-D), and FD3 (16SrV-C, reference strain FD-C). These clusters are accompanied with specific vector and reservoir plant-associated epidemiology or geographic distribution. The Map-FD1 and FD2 genotypes are characteristic for vineyards of France and Switzerland [7-9], whereas in Portugal, only FD-D is present [10]. All three genotype clusters are occurring in Italy, Croatia, and Hungary [8,11-15] while Map-FD2 and FD3 are present in Slovenia and Austria $[16,17]$. In Slovenian grapevine samples, the FD2 genotype is predominant, whilst in Austria, it is the FD3. However, in Serbia, solely the Map-FD3 (FD-C) is present $[8,18-20]$.

For a long time, it was commonly assumed that the FD pathogen, like the insect vector, was exotic, i.e., of North American origin [8]. Accordingly, epidemiological cycle of FDp was considered to involve only the ampelophagous $S$. titanus, which lives and feeds on grapevine in the European vineyards. However, findings of several natural plant reservoirs carrying FDp-related genotypes have revealed the native European origin of the pathogen, opened cycle of transmission, and polycyclic epidemiology [7-9,21,22]. European alder trees (Alnus glutinosa and A. incana) have been repeatedly found carrying diverse FDprelated genotypes and strains in many European countries, including Serbia $[7,15,16,23-28]$ and have been confirmed as asymptomatic reservoir plants primarily for Map-FD2 and FD1related genotypes [8]. In northern Italy and Serbia, the climbing shrub clematis (Clematis vitalba) has been proven as natural reservoir of FD-C, i.e., the Map-FD3 genotype of FDp [21,22], while this finding was also confirmed for Slovenia, Hungary, Switzerland, Austria, and wider territory of the Balkans $[9,13-15,20,25,29]$. Both of these host-associated genotypes are transmitted by specific vectors. In particular, native leafhoppers Allygus modestus and A. mixtus transmit Map-FD1 and FD2 genotypes sourced by alders [8], whereas native planthopper Dictyophara europaea transmits FD3 from clematis to grapevine [20,22]. Additionally, an alien leafhopper species of Asian origin, Orientus ishidae, found to be introduced in Europe from the year 2000 onwards [30-34] has been identified as another serious risk for spreading FD1 and FD2 genotypes in Slovenia, Italy, France, and Germany $[6,8,16,35,36]$, while in Switzerland it was found harboring all three FDp genotype variants [9]. O. ishidae in Serbia was just recently found established, still in habitats outside vineyards [37]. Thus, it has not had an impact on FD spread and epidemiology yet, at least not within the vineyards.

Along with alders and clematis, which are fairly well documented as FDp natural plant sources and feeding-plants of native or introduced insect vectors connecting natural plants and habitats with vineyard surroundings, there are several other tentative epidemiological constituents that could induce FDp outbreaks. It was recently found that tree of heaven (Ailanthus altissima), a vigorous invasive plant species, is carrying the 16SrV-C/Map-FD3 genotype in Italy, Croatia, and Bosnia and Herzegovina [15,38,39] and the 16SrV-D genotype in Slovenia [40], and could act as a reservoir of epidemics. In the aforementioned study in southern Switzerland, O. ishidae was found infected with FD-related phytoplasmas of all three map genetic clusters, all infecting the hazelnut (Corylus avellana) and FD1 infecting willow species (Salix spp.), thus suggesting that both plants could be additional hosts and reservoirs of FDp epidemics [9].

Occurrence of S. titanus and FDp was first recorded in Serbian vineyards in 2002 [41,42], although the presence of the vector is probably dated back to 1990s given its high population density at the time of the first record (Toševski I., unpublished data). Despite all efforts to contain the pathogen, including monitoring of disease and the vector, mandatory insecticide treatments against $S$. titanus and using phytoplasma-free certified planting material, the 
disease in Serbia is still spreading. Today, FD is affecting vineyard areas of all administrative districts in Serbia (Figure 1). The unique situation is that according to all of our upto-date analyzes of FDp-infected grapevines as well as the published data [8,18-20], all affected vineyards were infected with a single FDp genotype of the Map-FD3 genetic cluster, i.e., M51, despite being situated in environmentally diverse viticulture regions. The same genotype was also found, although on limited territory, to be involved in FDp outbreaks in Italy, Croatia, and Hungary [8,15].

Monotypic FDp epidemics in Serbian vineyards indicate the involvement of specific ecological components in disease outbreaks. Findings of C. vitalba, as well as A. glutinosa and $A$. incana, being natural FDp plant reservoirs [24,43] and D. europaea as a natural vector from clematis to grapevine $[20,22,44]$, shed some light on the epidemiology. However, as epidemic outbreaks continue to appear and disease is emerging in diverse habitats, it is clear that epidemiological pathways of transmission are evolving and adapting in the interaction between wild habitats and vineyard agroecosystem. Decoding these interactions and identification of all major constituents of the FD epidemiological cycle should help to prevent and control the spread of the disease. The first step towards this aim is to determine the genetic diversity of current FDp epidemic in Serbian wine-growing regions. The timing of the study is also of particular relevance, because it will show the diversity and ecological properties of the pathogen, prior to widespread establishment of Orientus ishidae and its influence on the disease spread and epidemiology.
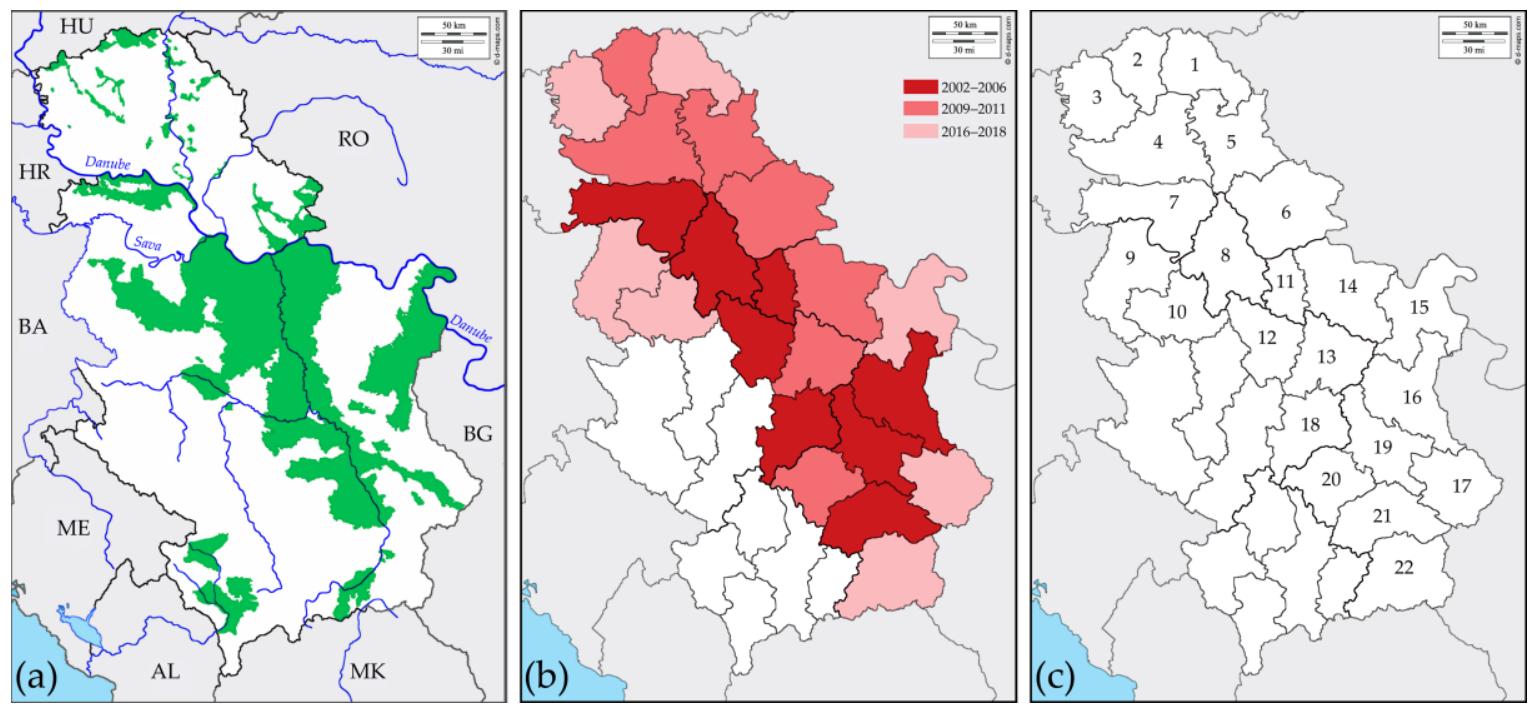

Figure 1. Geographic position of vineyards under study. In the images, it is presented: (a) distribution of wine-growing regions of Serbia [45], (b) districts of Serbia affected by Flavescence dorée (FD) colored according to year of first published record $[18,19,41]$ or first detection during our research surveys or within FDp surveillance programs, (c) administrative districts of Serbia (NUTS-3, https: / /ec.europa.eu/ eurostat/web/nuts/background (accessed on 31 December 2021)) sampled for FDp characterization as presented in Table 1. Numbers within each district correspond to the numbers denoting districts in Table 1. Maps are from d-maps.com, https://d-maps.com/carte.php?num_car=27556\&lang= en (accessed on 31 December 2021) and ttps:/ /d-maps.com/carte.php?num_car=27566\&lang=en (accessed on 31 December 2021).

\section{Materials and Methods}

\subsection{Grapevine Samples}

The FDp-infected symptomatic grapevine samples analyzed in this study were collected from 2017 to 2019 during our research surveys on the grapevine yellows phytoplasmas occurrence in Serbian vineyards or within the national FDp surveillance programs. Samplings were made in all administrative districts and wine-growing regions of Serbia (excluding Kosovo) during July and August of each year (Figure 1 and Table 1). The number 
of characterized FDp isolates (samples) per each district was determined in order to give a representative overview of genetic diversity of the pathogen strains in vineyards on the whole territory of Serbia. It was based on the combination of the size of wine-growing area within the district $[45,46]$, year of the first appearance of the FD disease (Figure 1) and the FDp incidence within the district observed during our field surveys and laboratory results over the years, as well as results of the national FDp surveys. Hence, the number of characterized FDp isolates per each administrative district in Serbia was between five and 25, whenever possible. Only in four districts where the overall number of FDp-infected grapevines was very low, the number of isolates selected for characterization was below five (Table 1).

Table 1. Sampling sites of symptomatic FDp-infected Vitis vinifera in vineyards of Serbia and associated map genotypes identified in this study.

\begin{tabular}{|c|c|c|c|c|c|c|}
\hline \multirow{2}{*}{ Region } & \multirow{2}{*}{ District } & \multirow{2}{*}{ Collection Date } & \multirow{2}{*}{$\begin{array}{c}\text { Number of } \\
\text { Characterized } \\
\text { FDp Isolates }{ }^{\text {a }}\end{array}$} & \multicolumn{3}{|c|}{ Number of Map Genotypes } \\
\hline & & & & M12 & M51 & Single $^{c}$ \\
\hline \multirow{7}{*}{ North Serbia } & 1. North Banat & August-2017, July-2018 & 20 & 19 & 1 & - \\
\hline & 2. North Bačka & July-2017, July-2018 & 20 & 16 & 4 & - \\
\hline & 3. West Bačka & July-2018, July-2019 & 20 & 15 & 5 & - \\
\hline & 4. South Bačka & August-2017, July-2018 & 10 & 1 & 9 & - \\
\hline & 5. Central Banat & July-2018 & 5 & 3 & 2 & - \\
\hline & 6. South Banat & July-2019 & 10 & - & 9 & M155 \\
\hline & 7. Srem & August-2017, July-2018 & 25 & - & 24 & M153 \\
\hline \multirow{6}{*}{ Central Serbia } & 8. Belgrade & August-2017, July-2018 & 15 & - & 14 & M154 \\
\hline & 9. Mačva & July-2018 & 3 & - & 2 & M148 \\
\hline & 10. Kolubara & July-2018, July-2019 & 2 & - & 1 & M148 \\
\hline & 11. Podunavlje & July-2018, July-2019 & 15 & - & 13 & M89, M152 \\
\hline & 12. Šumadija & August-2017, July-2019 & 10 & - & 9 & M151 \\
\hline & 13. Pomoravlje & August-2017, July-2019 & 10 & - & 9 & M150 \\
\hline \multirow{4}{*}{ East Serbia } & 14. Braničevo & August-2017, July-2018 & 5 & - & 5 & - \\
\hline & 15. Bor & July-2019 & 3 & - & 3 & - \\
\hline & 16. Zaječar & July-2018, July-2019 & 10 & - & 5 & M144 (5) \\
\hline & 17. Pirot & July-2018, July-2019 & 25 & - & 25 & - \\
\hline \multirow{5}{*}{ South Serbia } & 18. Rasina & August-2017, July-2018 & 25 & - & 25 & - \\
\hline & 19. Nišava & July-2017, July-2018 & 25 & - & 25 & - \\
\hline & 20. Toplica & July-2019 & 5 & - & 5 & - \\
\hline & 21. Jablanica & July-2018 & 5 & - & 5 & - \\
\hline & 22. Pčinja & July-2018 & 2 & - & 2 & - \\
\hline Total & & & 270 & 54 & 202 & 14 \\
\hline
\end{tabular}

${ }^{\text {a }}$ FDp identification was initially performed by amplification of FD9 marker (secY gene) or sec Y-map gene region in nested PCR or real-time PCR following previously published protocols $[7,11,47,48]$. Phytoplasma identification was confirmed on 16S rRNA gene using the P1/P7 and R16(V)F1/R1 primers in nested PCR protocol, and by TaqI restriction digestion of 16r758f/M23Sr nested PCR products [11]; ${ }^{\mathrm{b}}$ Map gene was amplified and characterized using the FDp-specific nested PCR protocol for secY-map gene region encoding methionine aminopeptidase [7]; Map genotypes were designated following established nomenclature [8], including designation of previously identified and published FDp-related genotypes from Montenegro, North Macedonia, and Serbia [20,26,27] (M142M149; Supplementary Materials Table S1) and newly identified genotypes detected in this study (M150-M155); ${ }^{\mathrm{c}}$ Genotypes found in single plant on location, except for genotype M144 which was identified in five samples. More details on localities of sampling sites and number of identified genotypes per locality are given in the Supplementary Materials Table S2. 


\subsection{Clematis vitalba, Ailanthus altissima, and Alnus glutinosa Samples}

The samples of natural plant reservoirs or secondary host plants of FDp in Serbia included isolates of Clematis vitalba collected in our previous study during 2011 and 2012 in the district of Rasina [20] (designated according to map nomenclature [8] in Supplementary Materials Table S1), and newly collected samples of Ailanthus altissima sampled during August 2017 on three locations in the major wine-growing regions of Serbia in the districts of Srem, Šumadija and Nišava (Supplementary Materials Table S3). To provide a better overview of natural diversity of the FDp in wild compartments of the Balkans and given the indication of its epidemic relevance for Serbian FDp epidemic [8], we added to the analysis the isolates of C. vitalba from Montenegro [20] and Alnus glutinosa from North Macedonia [27] (Supplementary Materials Table S3). We also designated all previously identified map genotypes from alders and clematis plants collected in Montenegro and North Macedonia according to established nomenclature [8] (Supplementary Materials Table S1).

\subsection{DNA Extraction and Phytoplasma Identification}

Total DNA was extracted from one gram of leaf midribs and petioles of symptomatic grapevine samples or asymptomatic Ailanthus altissima samples using a previously reported CTAB protocol [11]. The final total DNA pellet was resuspended in $100 \mu \mathrm{L}$ of TE buffer (10 mm TRIS, $1 \mathrm{mM}$ EDTA, pH 7.6). Extracted DNA was kept on $-20{ }^{\circ} \mathrm{C}$ until further analysis. The quality and concentrations of obtained DNA extracts were determined using a NanoPhotometer ${ }^{\circledR}$ N60 spectrophotometer (Implen, GmbH, Munich, Germany).

Initial FDp identification was performed by amplification of the FD9 genetic locus (secY gene) or secY-map genetic locus in conventional nested PCR or real-time PCR following previously published protocols $[7,11,47,48]$. Phytoplasma identification was confirmed on 16S rRNA gene using the P1/P7 [49,50] and R16(V)F1/R1 [51] primers in nested PCR protocol, and by TaqI endonuclease (MBI, Fermentas, Vilnius, Lithuania) restriction digestion of 16r758f/M23Sr [52,53] nested PCR products targeting 16S-23S ribosomal RNA gene, following previously described protocols [11]. The later analysis enabled identification of $16 \mathrm{SrV}-\mathrm{C}$ and -D subgroups of phytoplasmas based on RFLP (restriction fragment length polymorphism) profile [11]. Restriction fragments were separated with an automated capillary electrophoresis QIAxcel Advanced System (Qiagen, Hilden, Germany) with a high-resolution cartridge under previously described conditions [54]. All conventional PCR analyzes were performed in a Mastercycler ep Gradient S (Eppendorf, Hamburg, Germany) using FastGene Taq DNA polymerase (NIPPON Genetics Europe, Dueren, Germany), while real-time PCR analyzes were performed in Magnetic Induction Cycler (MIC, Bio Molecular Systems, Upper Coomera, QLD, Australia) using SsoAdvanced ${ }^{\mathrm{TM}}$ Universal SYBR ${ }^{\circledR}$ Green Supermix (Bio-Rad Laboratories, Inc., Hercules, CA, USA). Primers UNI28S-fwd/rev targeting eukaryotic $28 \mathrm{~S}$ rDNA were used as an endogenous control in real-time PCR analyzes [55].

The following phytoplasma isolates were employed as references for PCR/RFLP analysis: EY24_SRB, isolated from naturally infected Ulmus minor from Serbia [56]; Flavescence dorée FD-C isolated from naturally infected field-grown grapevine from the Nišava district (Serbia); FD-D isolated from naturally infected field-grown grapevine from the Veneto region (Italy) (provided by E. Angelini, Conegliano).

\subsection{FDp Genotyping}

To assess the genetic diversity, determine the origin and epidemiological source(s), and epidemic potential of FDp strains infecting grapevines in Serbia, all isolates (Table 1 and Supplementary Materials Tables S2-S4) were genotyped using house-keeping gene map which encodes methionine aminopeptidase [7]. Additionally, selected isolates (Supplementary Materials Tables S3 and S4) were also genotyped using vmpA adhesin-like gene which is involved in insect vector recognition and determines epidemic potential of different FDp and related strains, i.e., their compatibility to $S$. titanus and therefore potential to cause epidemic outbreak [8]. 
Amplification of map gene was performed by nested PCR using FD9f5MAPr1 and FD9f6MAPr2 primer pairs and sequenced using the MAPr2 primer, as previously described [7]. Sequencing was performed by Macrogen Europe (Amsterdam, The Netherlands), and nucleotide sequence data were deposited in the GenBank database under the accession numbers OL830352-OL830398 (Supplementary Materials Tables S3 and S4). Obtained sequences were aligned and compared with all reference map sequences using ClustalW integrated into MEGA5 software [57], i.e., with 132 map genotypes previously identified across Europe [8] and additional genotypes identified in our previous studies performed in Serbia, Montenegro, and North Macedonia (Supplementary Materials Table S1) [20,26,27], genotype from Croatia [15], and recent information on FDp-related genotypes found in alders and associated insect vectors in Switzerland [58]. Comparison was done to determine relatedness and host plant associations of different genotypes. Since population genetic peculiarities, intraspecific variations, and relationships resulting from underlying population dynamics such as the persistence of ancestral haplotypes, recombination, horizontal transfers, and recurrent mutations are better visualized in reticulograms or networks than in evolutionary gene trees [59-61], the assessment of the evolutionary relatedness and genealogy of the map genotypes was done by constructing the genotype network. Networks were constructed using the software PopART version 1.7 (http:/ / popart.otago.ac.nz (accessed on 31 December 2021)) based on gene genealogies inferred by performing median-joining (MJ) calculation [62], keeping the parameter e $=0$. To study the correlations among the different genotypes, their host plant associations and geographic origin, two networks were constructed: (i) with all up-to-date published map genotypes and information on their host(s), and (ii) with map genotypes identified in the Balkans, including their frequencies detected in this study and their host association, i.e., ecological properties.

The vmpA gene, encoding the Variable membrane protein $\mathrm{A}$, was amplified using VmpA-F5/VmpA-R3 primer pair for direct PCR and VmpA-F8/VmpA-R7 primers for nested PCR, using FastGene Optima HotStart Ready Mix (NIPPON Genetics Europe, Dueren, Germany) following previously described thermal protocols [8]. Obtained amplicons were sequenced using the VmpA-F3 and VmpA-R5 primers, as previously defined [8], and nucleotide sequence data were deposited in the GenBank database (OL907155OL907208; Supplementary Materials Tables S3 and S4). The vmpA sequences were aligned, edited and compared with reference sequences using ClustalW. Genetic diversity among different $v m p A$ genotypes was assessed on two levels using two approaches. Firstly, correlations among the different genotypes from clusters VmpA-II and VmpA-III hosting epidemic genotypes of FDp [8] were studied by the median-joining network analysis [62], performed in PopART based on the 234-bp sequences of the first repeat (R1) of the vmpA gene of FDp and related strains found in grapevine and alternative host-plants in Europe $[6,8,13]$ as well as the data from this study. Secondly, diversity of nearly full-length vmpA gene sequences (PS, signal peptide + R1-R4 repeated domains) of isolates detected in this study was studied by constructing the unrooted neighbor-joining tree. The tree was generated in MEGA5 software [57] with evolutionary distances computed using the number of differences method and 500 bootstrap replicates.

\section{Results}

\subsection{Diversity and Incidence of FDp Map Genotypes in Serbian Vineyards}

Map gene typing of 270 FDp-infected grapevine isolates sampled from 2017 to 2019 in 22 administrative districts, covering all wine-growing regions of Serbia (Figure 1), resulted in identification of 11 different genotypes. Eight of these genotypes (266 isolates) belong to the genetic cluster Map-FD3, while three genotypes (four isolates) belong to the cluster FD2 (Figure 2 and Table 1). PCR/RFLP analysis of 16S-23S ribosomal RNA gene region confirmed that all the isolates are members of the $16 \mathrm{SrV}-\mathrm{C}$ phytoplasma subgroup (data not shown). 
(a)
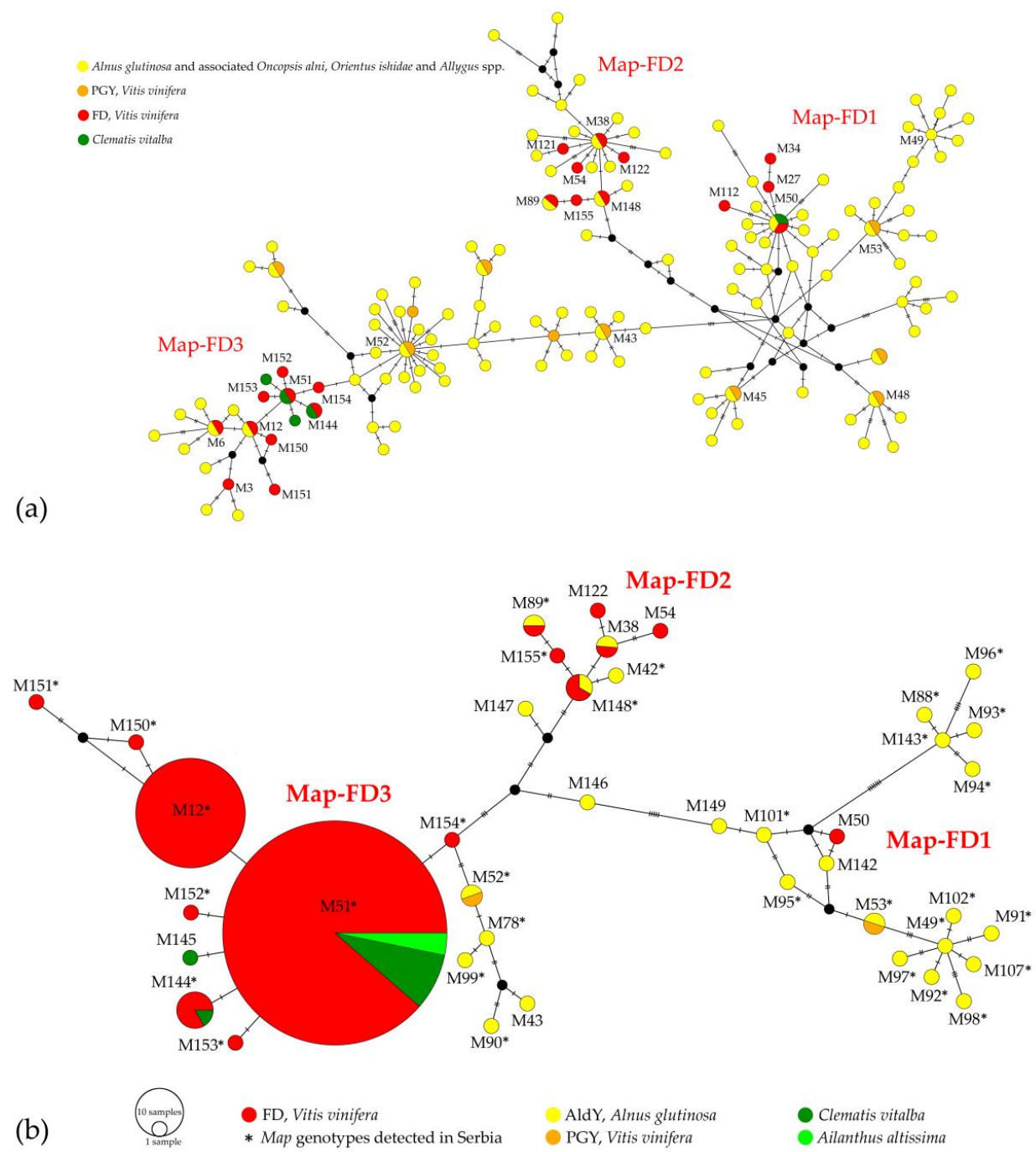

Figure 2. Median-joining networks inferred from map genotypes of FDp and related strains. Genotypes are represented by circles and paired genotypes are connected by a line. Each SNP mutation is represented by a hatch mark, while black dot vertices represent median vectors. Host association(s) of genotypes is represented by different color(s) of circles as shown in the figure legends. (a) Network and host associations of a total of 146 map genotypes previously identified across Europe $[8,15,20,26,27,58]$ and those identified in this study. Each genotype is represented by the same circle size except those found in multiple hosts. For better visibility of the network structure and connections the genotype designation is given only for those of the Map-FD1, FD2 and FD3 clusters found in grapevine (FD, red circles) and for the main genotypes of the AldY/PGY clusters (yellow and orange circles); the same network with designation of all 146 map genotypes of FDp and related strains is given in the Supplementary Materials Figure S1. (b) Network of a total of 41 map genotypes previously identified in the Balkans $[8,15,20,26,27]$ and those identified in this study. Map genotypes detected in Serbia are marked with an asterisk $(*)$. Different circle size shows the frequency of genotypes identified in this study (Table 1). Genotype frequencies in Clematis vitalba are taken from previous study [20], i.e., M51 (18) and M144 (1). Genotypes were designated following established nomenclature [8], including designation of previously identified and published FDp-related genotypes from Montenegro, North Macedonia and Serbia [20,26,27] (M142-M149; Supplementary Materials Table S1) and newly identified genotypes detected in this study (M150-M155).

Among detected genotypes from the Map-FD3 cluster, only two were previously reported in FD outbreaks across Europe, namely M12 and M51. One genotype, M144, was newly detected in grapevine, although previously identified in Clematis vitalba from 
Serbia [20], while five genotypes (M150-M154) were for the first time recorded for any host and these were all infecting single plants. The most abundant was the M51 genotype, infecting 202 out of 270 isolates (75\%). It was found in all wine producing regions of Serbia (Figure 3) and was the dominant or the only FDp epidemic genotype in most of the districts (Table 1). However, multiple outbreaks of the M12 genotype, differing in single nucleotide polymorphism (SNP) from M51, were recorded in five districts in north Serbia, infecting 54 isolates (20\% of the total number of isolates). This genotype was dominant in three districts bordering with Croatia, Hungary and Romania (Figure 3). Outbreak of a new endemic Map-FD3 genotype M144, also a SNP variant of M51, was documented in grapevine samples from Zaječar district in east Serbia (5 isolates). Single grapevine infections with five new Map-FD3 genotypes M150-M154 were all recorded in central Serbia. Three of these genotypes (M152, M153 and M154) are SNP variants of M51, while genotypes M150 and M151 are single and three SNP variants of M12, respectively (Figure 2).
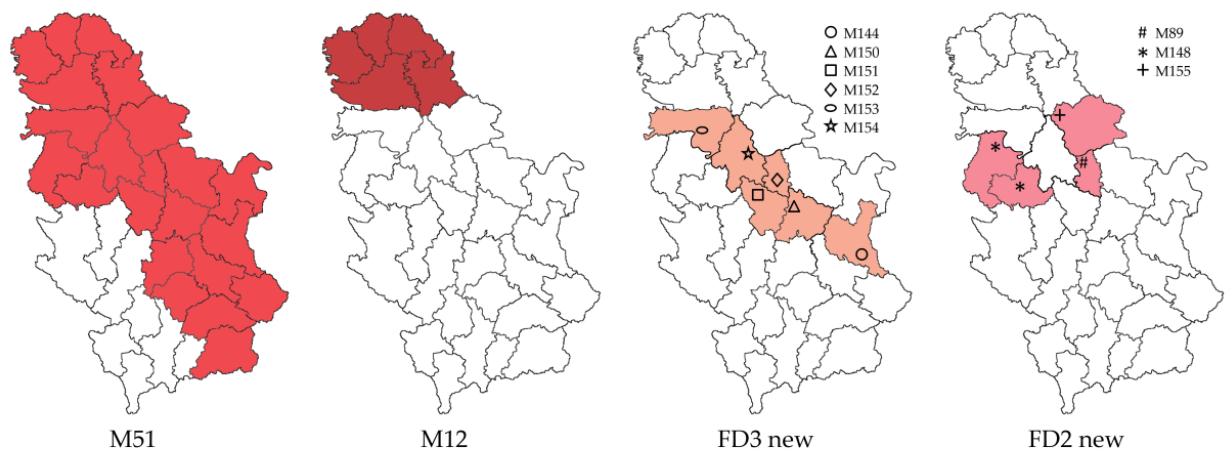

Figure 3. Geographic distribution of the FDp map genotypes identified in grapevine in Serbian vineyards according to administrative districts. Maps are from d-maps.com, https: / d-maps.com/ carte.php?num_car=27603\&lang=en (accessed on 31 December 2021).

Genotypes of the Map-FD2 cluster, namely M89, M148 and M155, where all new, for the first time detected in grapevine and they were all identified in single plant infection on location. However, genotype M89 was previously identified in Alnus glutinosa from Serbia [8,24], while M148 was detected in FDp-infected grapevine in two districts of Serbia (Table 1) and was previously identified in A. glutinosa from North Macedonia [27]. The M148 is a SNP variant of M42 genotype associated with alders from Serbia which was predicted to have epidemic potential for FD outbreak [8], as well as the SNP variant of M38, a genotype that is widely distributed and often occurring in alders as well as in the FD outbreaks across Europe. Genotypes M155 and M89 are two and three SNP variants of M42, as well as of M38, respectively (Figure 2).

Detail overview of geographic distribution of FDp epidemic map genotypes infecting grapevine in Serbia is presented in Figure 3.

\subsection{Diversity of FDp VmpA Genotypes in Serbian Vineyards}

Sequencing of a non-neutral vmpA gene was performed for a panel of 42 grapevine isolates selected to give an overview of FDp strain diversity in all wine-growing regions of Serbia (Supplementary Materials Table S4). A total of 22 M51 isolates (one per each district of occurrence), eight M12 isolates (two per most affected districts and one per additional two districts of occurrence) all five M144, each of the new Map-FD3 genotypes (M152, M153 and M154), and all four isolates from Map-FD2 cluster (M89, M148 and M155) were analyzed. Unfortunately, we could not obtain the vmpA gene amplification for genotypes M150 and M151, probably due to low phytoplasma concentration $(\mathrm{Cq}=35)$, thus these were not included in the analyzes. The vmpA nested PCR amplicons of all Map-FD3 isolates, as well as of two isolates of the Map-FD2 M148 genotype, were of 1956-bp in size, thus including four complete repeats of 234-bp repeated domain (R1-R4). The Map-FD2 
genotypes M89 and M155 had 1722-bp long vmpA amplicons which indicated on deletion of repeat R4, typically found in VmpA-II sequences including the reference FD92 strain [8].

Genotype network analysis of the 234-bp sequences of the first repeat (R1) of the vmpA gene of FDp and related strains found in grapevine and alternative host-plants in Europe, along with isolates from this study, enabled classification of 11 genotypes into two clusters, VmpA R1-II and III (Figure 4). The VmpA R1-II cluster hosted five genotypes designated as II-a, -b, -c, -d, and -e. The vmpA R1 sequences of all grapevine isolates from Serbia that were associated with Map-FD2 cluster (M89, M148 and M155) were carrying the R1 genotype II-d. The VmpA R1-III cluster is consisted of six genotypes designated as III-a, -b, -c, -d, -e, and -f. Grapevine isolates from Serbia belonging to the Map-FD3 cluster were carrying three different VmpA R1 genotypes: III-b, III-c, and III-d (Table 2); differing in three, four, and seven SNPs among them (Figure 4). All grapevine isolates of M144 map genotype were associated with III-b VmpA R1 genotype, while all isolates of M12 were associated with III-d (Table 2). Among 22 characterized grapevine isolates of the M51 genotype, all but one, VS-18-98, were carrying III-c VmpA R1 genotype, while this single isolate was carrying III-b.

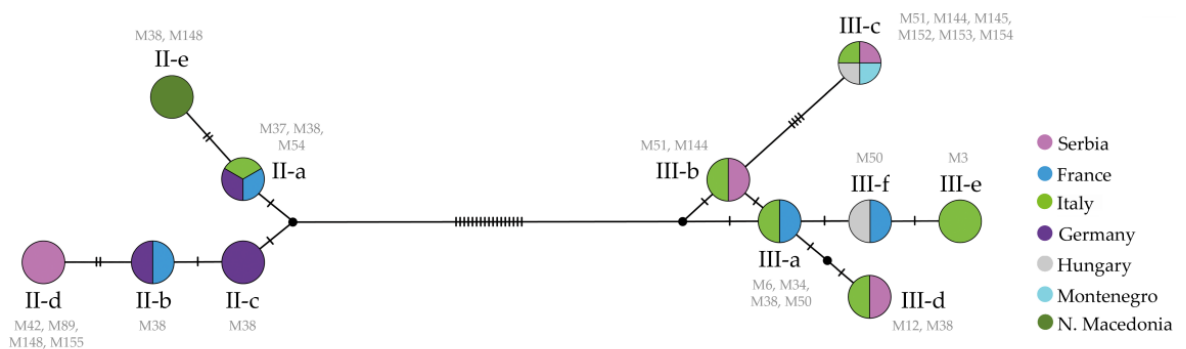

VmpA R1-II

VmpA R1-III

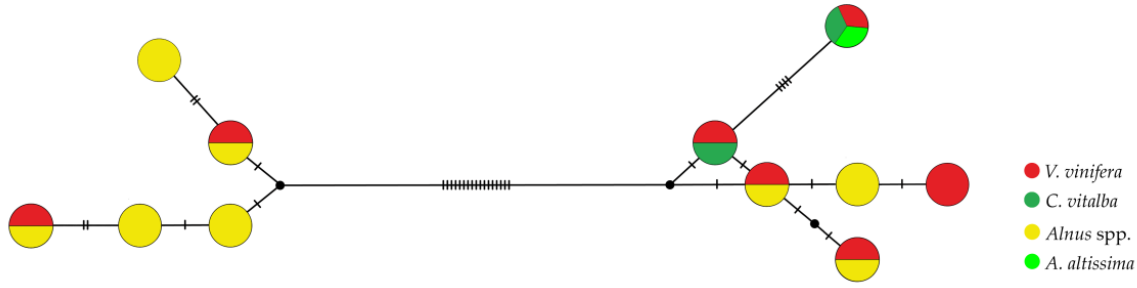

Figure 4. Median-joining networks inferred from the 234-bp sequences of the first repeat (R1) of the $v m p A$ gene of FDp and related strains found in grapevine and alternative host-plants in Europe. The VmpA R1 cluster genotypes are represented by circles and paired genotypes are connected by a line. Each SNP mutation is represented by a hatch mark, while black dot vertices represent median vectors. Networks are identical except for information on the origin of phytoplasma isolates carrying designated genotypes. As shown in the figure legends of upper and lower picture, different color(s) of circles represent geographic origin and host plant association(s) of the vmpA R1 genotypes, respectively. Each $v m p A$ R1 genotype on the upper picture is designated according to VmpA cluster and $\mathrm{R} 1$ repeated domain type using black font roman numbers followed by alphabetic subdivision (II-a, ... , II-e and III-a, ... , III-f), as well as according to the associated map genotype(s) denoted in grey font. Data on the occurrence of vmpA R1 genotypes in different hosts in Serbia are either from this study or from previously published findings [8]; data for Montenegro and North Macedonia are from this study, while data for France, Germany, and Italy are taken from previous studies [6,8,13].

Sequence analysis of nearly full-length vmpA gene (PS + R1-R5 repeated domains) of grapevine isolates detected in this study enabled recognition of higher level of diversity, as well as classification and comparison of $\operatorname{vmpA}$ strains in more details (Figure 5 and Table 2). Among isolates of the II-d R1 genotype, three sequence types were identified, two of which were associated with grapevine in Serbia, namely II-d2 (map M89 and M155) and II-d3 (M148). Isolates of the $v m p A$ sequence type II-d2 were the only one with a total number of four repeated domains (R4 deletion; Table 2). Isolates of III-b R1 genotype had two different 
vmpA sequence types; one associated with all five isolates of M144 (III-b1) and one with single isolate of M51, VS-18-98 (III-b2). Among the most abundant isolates of the III-c R1 genotype, 12 different $v m p A$ sequence types were identified (III-c1 to III-c12), of which all but one (III-c12) were detected in grapevine samples from Serbia in this or in a previous study [8] and were associated with M51, M152, M153, and M154 map genotypes. Finally, isolates of III-d R1 genotype had three different vmpA sequence types, but all grapevine samples of map M12 genotype from Serbia had an identical sequence designated as III-d1 sequence type.

Table 2. The FDp vmpA sequence diversity sorted according to cluster and type of R1 repeated domain as presented in Figure 5. Number of repeated domains and their identity is indicated. Associated Map genetic cluster and map genotype are given, along with information on representative isolate or identity to representative isolate and host(s).

\begin{tabular}{|c|c|c|c|c|c|c|}
\hline \multicolumn{3}{|c|}{ VmpA } & \multicolumn{2}{|c|}{ Associated Map } & \multirow{2}{*}{$\begin{array}{l}\text { Representative Isolate or } \\
\text { Identity (Sequence Type) }{ }^{\text {a }}\end{array}$} & \multirow{2}{*}{ Host (No) ${ }^{b}$} \\
\hline $\begin{array}{l}\text { Cluster-R1 } \\
\text { Type }\end{array}$ & $\begin{array}{l}\text { No of Repeated } \\
\text { Domains }\end{array}$ & $\begin{array}{l}\text { Identical } \\
\text { Domains }\end{array}$ & Cluster & Genotype & & \\
\hline \multicolumn{7}{|c|}{ Malembic-Maher et al. 2020 Plos Pathogens [8] } \\
\hline \multirow{3}{*}{ II-a } & 4 & no & FD2 & M54 & FD92 & $\mathrm{Vv}$ \\
\hline & 4 & no & FD2 & M37 & AF-06-30-25 & Ald \\
\hline & 4 & no & FD2 & M38 & FG-15-124 & Ald \\
\hline II-b & 4 & no & FD2 & M38 & AG-15-115 & Ald \\
\hline II-c & 4 & no & FD2 & M38 & AG-09-22-7 & Ald \\
\hline II-d & 5 & $\mathrm{R} 2, \mathrm{R} 3$ & FD2 & M42 & AS-AL21 & Ald \\
\hline \multirow[t]{2}{*}{ III-a } & 5 & $\mathrm{R} 3, \mathrm{R} 4$ & FD1 & M50 & FD70 & $\mathrm{Vv}$ \\
\hline & 5 & $\mathrm{R} 2, \mathrm{R} 4$ & FD1 & M34 & VF-04-11-19 & Vv \\
\hline III-c & 5 & $\mathrm{R} 2, \mathrm{R} 3$ & FD3 & M51 & VS-Loza232 & $\mathrm{Vv}$ \\
\hline III-c & 5 & $\mathrm{R} 2, \mathrm{R} 3, \mathrm{R} 4$ & FD3 & M51 & CH-B37 & $\mathrm{Cl}$ \\
\hline III-d & 5 & no & FD3 & M12 & $\mathrm{Vv}-\mathrm{AO} 262$ & $\mathrm{Vv}$ \\
\hline III-e & 5 & $\mathrm{R} 2, \mathrm{R} 3$ & FD3 & M3 & VI04-C28 & Vv \\
\hline III-f & 5 & $\mathrm{R} 2, \mathrm{R} 3, \mathrm{R} 4$ & FD1 & M50 & AH-B38 & Ald \\
\hline \multicolumn{7}{|l|}{ This study } \\
\hline \multirow[t]{3}{*}{ II-d } & 4 & $\mathrm{R} 2, \mathrm{R} 3$ & FD2 & M89 & $\begin{array}{c}=\mathrm{AS}-\mathrm{AL} 21, \mathrm{R} 4 \text { deletion } \\
\text { (II-d2) }\end{array}$ & Vv (1) \\
\hline & 4 & $\mathrm{R} 2, \mathrm{R} 3$ & FD2 & M155 & $\begin{array}{c}=\mathrm{AS}-\mathrm{AL} 21, \mathrm{R} 4 \text { deletion } \\
\text { (II-d2) }\end{array}$ & $\mathrm{Vv}(1)$ \\
\hline & 5 & $\mathrm{R} 2, \mathrm{R} 4$ & FD2 & M148 & 99.7\% AS-AL21 (II-d3) & $\mathrm{Vv}(2)$ \\
\hline \multirow[t]{2}{*}{ II-e } & 5 & $\mathrm{R} 2, \mathrm{R} 3, \mathrm{R} 4$ & FD2 & M148 ${ }^{c}$ & 99\% AS-AL21 (II-e) & Ald (1) \\
\hline & 5 & $\mathrm{R} 2, \mathrm{R} 3, \mathrm{R} 4$ & FD2 & $\mathrm{M} 38^{\mathrm{c}}$ & 99\% AS-AL21 (II-e) & Ald (1) \\
\hline \multirow[t]{2}{*}{ III-b } & 5 & $\mathrm{R} 3, \mathrm{R} 4$ & FD3 & M144 & 99.7\% FD70 (III-b1) & $\mathrm{Vv}(5)$ \\
\hline & 5 & no & FD3 & M51 & 99.5\% FD70 (III-b2) & Vv (1) \\
\hline \multirow[t]{14}{*}{ III-C } & 5 & no & FD3 & M51 & 99.3\% VS-Loza232 (III-c1) & $\mathrm{Vv}(3)$ \\
\hline & 5 & no & FD3 & M51 & $99.3 \%$ VS-Loza232 (III-c2) & Vv (1) \\
\hline & 5 & $\mathrm{R} 3, \mathrm{R} 4$ & FD3 & M51 & $99.5 \%$ VS-Loza232 (III-c3) & $\mathrm{Vv}(2), \mathrm{Cl}(1), \mathrm{Aa}(2)$ \\
\hline & 5 & no & FD3 & M51 & $99.8 \%$ VS-Loza232 (III-c4) & $\mathrm{Vv}(1), \mathrm{Cl}(1), \mathrm{Aa}(2)$ \\
\hline & 5 & no & FD3 & M51 & 99.8\% VS-Loza232 (III-c5) & $\mathrm{Vv}(1)$ \\
\hline & 5 & $\mathrm{R} 2, \mathrm{R} 3, \mathrm{R} 4$ & FD3 & M51 & $=\mathrm{CH}-\mathrm{B} 37$ (III-c6) & $\mathrm{Vv}(2), \mathrm{Aa}(1)$ \\
\hline & 5 & $\mathrm{R} 2, \mathrm{R} 4$ & FD3 & M51 & 99.4\% VS-Loza232 (III-c8) & $\mathrm{VV}(1)$ \\
\hline & 5 & no & FD3 & M51 & 99.7\% VS-Loza232 (III-c9) & Vv (1) \\
\hline & 5 & $\mathrm{R} 2, \mathrm{R} 3$ & FD3 & M51 & =VS-Loza232 (III-c11) & $\mathrm{Vv}(9), \mathrm{Cl}(3), \mathrm{Aa}(2)$ \\
\hline & 5 & $\mathrm{R} 2, \mathrm{R} 3, \mathrm{R} 4$ & FD3 & M152 & $=\mathrm{CH}-\mathrm{B} 37$ (III-c6) & Vv (1) \\
\hline & 5 & $\mathrm{R} 2, \mathrm{R} 3$ & FD3 & M153 & $=$ VS-Loza232 (III-c11) & $\mathrm{Vv}(1)$ \\
\hline & 5 & no & FD3 & M154 & 99.3\% VS-Loza232 (III-c1) & $\mathrm{Vv}(1)$ \\
\hline & 5 & no & FD3 & M144 ${ }^{\mathrm{d}}$ & 99.6\% VS-Loza232 (III-c12) & $\mathrm{Cl}(1)$ \\
\hline & 5 & $\mathrm{R} 2, \mathrm{R} 4$ & FD3 & M145 ${ }^{\mathrm{d}}$ & 99.4\% VS-Loza232 (III-c8) & $\mathrm{Cl}(1)$ \\
\hline III-d & 5 & no & FD3 & M12 & = v-AO262 (III-d1) & Vv (8) \\
\hline
\end{tabular}

${ }^{a} \operatorname{VmpA}$ representative isolate of cluster and R1 type [8] or identity of isolates detected in this study compared to representative isolate and sequence type according to Figure $5 ;{ }^{\mathrm{b}}$ Hosts: Ald = alder (Alnus glutinosa), $\mathrm{Vv}=$ grapevine (Vitis vinifera), $\mathrm{Cl}$ = clematis (Clematis vitalba), $\mathrm{Aa}=$ tree of heaven (Ailanthus altissima); No: number of isolates per host identified in this study; ${ }^{\mathrm{c}}$ Data from [27]; ${ }^{\mathrm{d}}$ Data from [20]. 


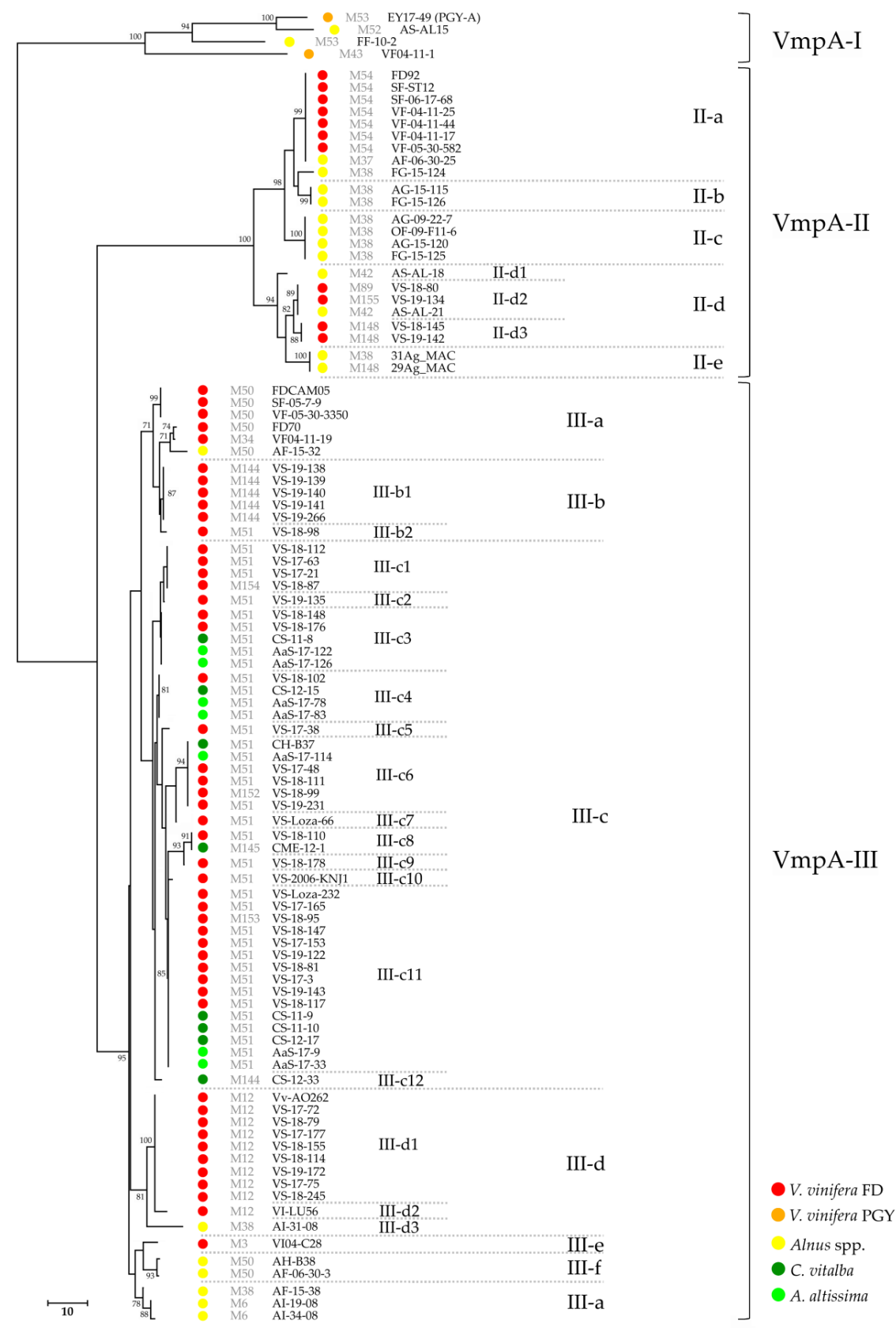

Figure 5. The unrooted neighbor-joining tree showing sequence diversity of $v m p A$ gene (PS, signal peptide $+\mathrm{R} 1-\mathrm{R} 4$ repeated domains) encoding Variable membrane protein A of FDp and related strains. Major VmpA genetic clusters are shown along the brackets and are designated according to previously published nomenclature [8]. The corresponding VmpA R1 cluster genotypes (vmpA R1 genotypes as defined on Figure 4) are designated on long dotted lines, while vmpA sequence types $(\mathrm{PS}+\mathrm{R} 1-\mathrm{R} 4)$ are given on short dotted line. Each isolate is designated in black font and preceding grey text designates associated map genotype for each isolate. Different color of circles next to the each isolate represent host plant association of the isolate as shown in the figure legend. The $v m p A$ sequence types are denoted only for $v m p A$ R1 genotypes detected in samples from this study and our previous studies conducted in Serbia, Montenegro and North Macedonia [20,24,26,27]. Except for previously described phytoplasma isolates [8], the details and GenBank accession numbers for each isolate detected in this study are provided in Supplementary Materials Tables S3 and S4. The tree was generated in MEGA5 with evolutionary distances computed using the number of differences method which are in the units of the number of base differences per sequence. Bootstrap values for 500 replicates are indicated along the branches when $>70$. 


\subsection{Ecological Components of FDp Epidemiological Cycle in Serbia}

Natural plant reservoirs or secondary host plants of FDp analyzed to give an overview of possible routes of disease transmission included samples of M51 and M144 genotypes previously found in Clematis vitalba from Serbia and M145 in Montenegro [20], isolates of Alnus glutinosa hosting M38 and M148 genotypes from North Macedonia [27], and seven newly collected samples of FDp-infected Ailanthus altissima from Serbia. Isolates from A. altissima all proved to be infected with the M51 genotype on three sampling locations, thus having a tentative role as an additional Map-FD3 reservoir plant in Serbian vineyards, along with $C$. vitalba. Confirmation on the occurrence of the same map genotype, i.e., M144, in C. vitalba and in grapevine in Serbia, in addition to the known co-occurrence of M51 in both plants, provides further evidence on the primary role of C. vitalba in Map-FD3 epidemiology (Figure 2). On the other hand, findings of the same M148 genotype in grapevine samples from two locations in Serbia and its identification in A. glutinosa from North Macedonia, as well as the finding of M89 in grapevine and in A. glutinosa on habitats outside vineyards in Serbia, provided first solid proof that alders can be natural hosts and sources of Map-FD2 epidemics in the Balkans, the same way they are in a western European vineyards.

Analyses of the $v m p A$ gene sequence diversity of the isolates from alternative FDp host plants further confirmed their tight connections to FD outbreaks (Figure 6). Among the seven C. vitalba isolates (M51, M144 and M145) analyzed for vmpA gene variability, all were carrying the R1 genotype III-c (Figure 4, Table 2 and Supplementary Materials Table S2), even the M144 genotype which is in grapevine associated with III-b genotype. However, an identical $\operatorname{mp} A$ sequence as the R1 III-b was previously found in C. vitalba, although not in Serbia but in a region of Piedmont in north-western Italy (designated as vmpA_R1_3) [13], thus confirming the correlation between the FDp M144/III-b genotype, FD outbreaks and C. vitalba as the source plant. For the $C$. vitalba isolates of M51 genotypes, the connection to FDp epidemics is more pronounced because four vmpA sequence types found infecting C. vitalba (III-c3, c4 and c11 in isolates from Serbia and III-c6 from Hungary [8]), are identical to those found in FD outbreaks. The situation is very similar when considering Ailanthus altissima as a reservoir plant of the Map-FD3. The same four $v m p A$ sequence types which were found infecting C. vitalba (III-c3, c4, c6 and c11) were also identified in A. altissima, thus connecting the two plants with the grapevine as FDp source of the epidemics (Figure 6).

Regarding Alnus glutinosa plants as natural reservoirs and source of the Map-FD2 epidemics, the $v m p A$ sequence analysis confirmed epidemiological connections derived from the map gene, and revealed further complexity of the relations. Identical vmpA sequence type II-d2 was detected in Serbian alder AS-AL-21 (M42) and in grapevine isolates VS-18-80 (M89) and VS-19-134 (M155), albeit with the deletion of the R4 repeated domain (Figure 6). Moreover, isolates of M148 genotype (VS-18-145 and VS-19-142) had only slightly different $v m p A$ sequence type of II-d3. However, both the M148 alder isolate from North Macedonia and the M38 alder-associated genotype were found to carry the VmpA R1 II-e genotype and $v m p A$ sequence type unique to this geographic area or for specific vector(s). 


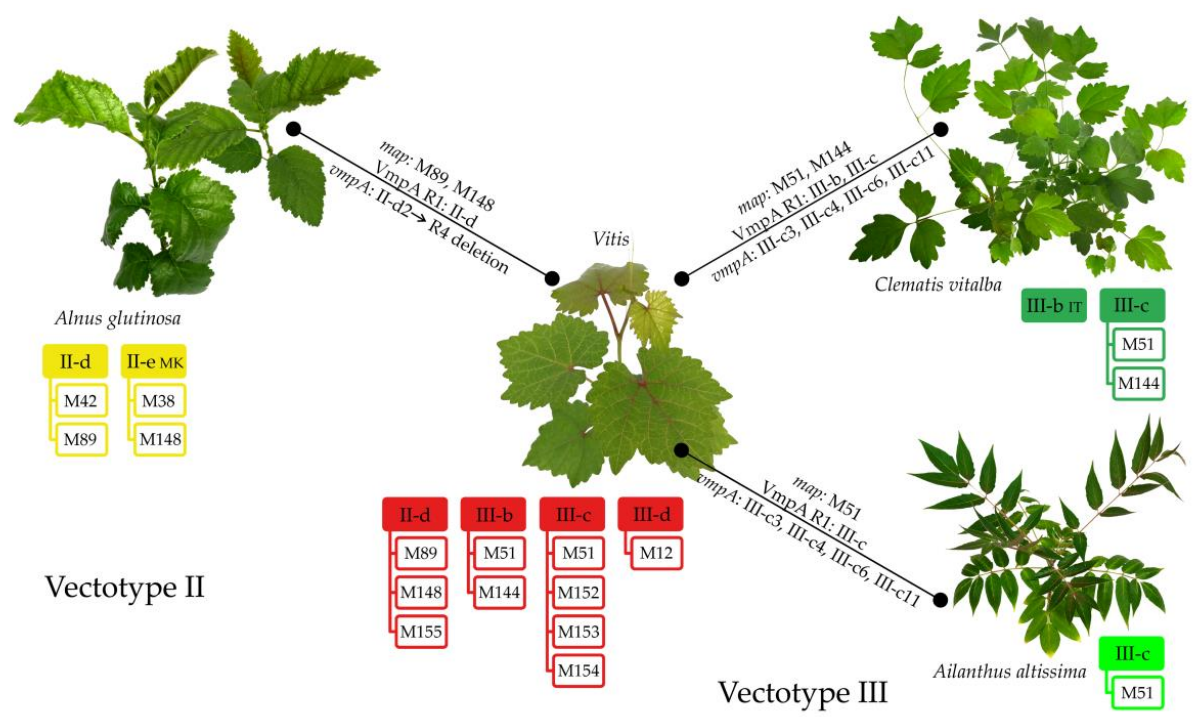

Figure 6. Schematic overview of FDp epidemiological Vectotypes detected in Serbia sorted according to genotypes found in FD-infected vines and in reservoir host plants. The FDp genotypes presented above and below connection lines between grapevine and reservoir plants are those found in both hosts and are defined on the three bases: (i) the map genotype, (ii) the VmpA R1 cluster genotypes (both presented above connection line) and (iii) the vmpA PS + R1-R4 sequence type as denoted in Figure 5 (presented below connection line). Vectotype nomenclature and designation are according to original study on FDp vectotypes [8]. Data on the FDp genotypes occurrence in different hosts in Serbia are either from this study or from previously published findings $[8,20,24]$. All presented Vectotypes are identified in grapevine and/or in reservoir/alternative host(s) sampled in Serbia, except for the FDp VmpA R1 II-e genotype (and its map genotypes) of Vectotype II associated with Alnus glutinosa in North Macedonia [27], VmpA R1 III-b genotype of Vectotype III associated with Clematis vitalba in Piedmont, Italy (vmpA_R1_3, [13]) and vmpA PS + R1-R4 sequence type III-c6 found in C. vitalba in Hungary [8].

\section{Discussion}

Epidemic outbreaks of Flavescence dorée in vineyards of Serbia first emerged in early 2000s [41] and were directly associated with dense populations of an alien invasive leafhopper vector Scaphoideus titanus [42]. The disease, along with its insect vector, spreads quickly to several major viticulture regions of Serbia [18] and has continued to spread despite preventive and control measures, affecting all wine-growing regions in Serbia today (Figure 1). The FD phytoplasma, a pathogen causing the disease, was first treated as alien that was introduced like its insect vector. However, genetic peculiarities of FDp isolates from Serbia [22,63], as well as its occurrence in native plants of Alnus spp. in riparian areas [24], and Clematis vitalba in vineyard surroundings and in natural habitats [43], including identification of native planthopper Dictyophara europaea as the FDp vector from C. vitalba to grapevine [22], proved otherwise. The genetic diversity of FDp in the vineyards of Serbia presented in this study further provided explicit evidence of this phytoplasma's genetic uniqueness, autochthonous origin, and endemic emergence of new epidemic genotypes.

Most of FDp outbreaks in Serbian vineyards are caused by the M51 genotype from Map-FD3 cluster which is widespread in all districts and wine-growing regions. It is the genotype of the original FD epidemics in the 2000s and it is still the dominant one in most regions. However, the $\operatorname{mmp} A$ typing revealed diverse strains associated with M51 (11 sequence types of VmaA R1 III-c genotype and one from III-b), thus indicating on multiple emergences. All strains had five $\operatorname{vmpA}$ repeated domains, but in some of them, recent duplication events are evidenced by complete identity among different repeats (Table 2). It has been previously hypothesized that domain duplication in $v m p A$ is a possible adaptation trait to Deltocephalinae leafhopper vectors, thus enabling compatibility 
of FDp strains to be transmitted by S. titanus [8]. In the case of Serbian M51 epidemics, FDp emergence in grapevine is connected with $C$. vitalba as a primary source plant and probably with Ailanthus altissima as a newly reported, tentative secondary or alternative FDp host plant that could be connected to $C$. vitalba through polyphagous vectors such as D. europaea $[20,44]$. Connection between FDp strains in C. vitalba and A. altissima was previously evidenced for Italy [38], and the same could be expected in Serbia as well. However, further detailed FDp genotyping of more variable genes such as imp or malG $[13,38]$ would be needed to provide evidence of this relation. Given the level of ecological and epidemiological complexity of these relations, the vmpA diversity of FDp strains involved in the Serbian epidemic could be their reflection, while detailed surveys on the leafhopper fauna involved in such interactions are of urgent need. We still do not know how vmpA adapts and changes in response to planthopper vectors such as D. europaea. On the other hand, we do know that native polyphagous leafhopper vectors, Allygus mixtus and A. modestus, proven to make epidemiological connections between alders and grapevine in France and Germany [6,8], are widespread in Serbian forests, meadows, and agroecosystems [64-66] including vineyards [67]. Occurrences of the VmpA R1 III-b genotype in grapevine and emergence of new M144/III-b strain in the vineyards of east Serbia again points to clematis as a source plant (Figure 6) [13]. Divergence of $v m p A$ indicates a new vector(s) which could easily be species of Allygus or some closely related Deltocephalinae.

Apart from the Serbian M51 FDp epidemic, this same genotype was only found in the vineyards of neighboring Croatia and Hungary $[8,14,15]$, and in a single grapevine sample from the Tuscany region in central Italy collected in 2007 (FN811141) [68]. The autochthonous origin of M51 epidemics in Serbia is thus unquestionable, based on the time of emergence, diversity, and natural reservoir plants. This is further corroborated by the emergence of new Map-FD3 genotypes (M150-M154), indicating high endemic potential for new outbreaks. Independent of the plant source, the vmpA typing placed all Map-FD3 isolates into the VmpA-III cluster, i.e., Vectotype III. The newly established concept of Vectotypes is based on the information provided by typing the explicative genetic markers of Vmps [8]. Vectotype of FDp is therefore a phytoplasma strain carrying a given type of non-neutral marker, in this case of $v m p A$, able to achieve a complete transmission cycle in a given insect, i.e., in S. titanus as the main vector of FDp epidemics. The VmpA is an adhesion related protein of FDp which enables bacterial adhesion to insect cells [69] and seems to have a key role in phytoplasma invasion of insect cells and adaptation to different vectors through duplication of pre-adapted repeated domains [8]. As a result, the identification of VmpA types of the Vectotype III in all isolates from Map-FD3 cluster and in all plant hosts indicates their epidemic nature, transmissibility by $S$. titanus and reservoir plants.

Regarding newly identified epidemic outbreaks of the map M12 FDp genotype in north Serbia, the information available from literature and that obtained in our study is insufficient for a conclusive statement on the origin of this epidemic. We can pin-point the year of its emergence to 2017, but we cannot currently tell if this genotype escaped from alders or clematis in Serbia, or if it has been introduced with planting material. The occurrence of the M12 epidemic was evidenced for viticultural region of Piedmont in northwestern Italy as early as 2004 (LT221907, isolate VI04-188-04) [8] and was still ongoing in 2013 [13], albeit in co-occurrence with the M54 genotype of Map-FD2 as the dominant FDp strain in the region. The presence of the M12 is also known for the Valle d'Aosta region of north-western Italy in 2006 (LR585140, isolate Vv-AO262) and Tuscany in central Italy in 2010 (LR585139) [8]. All Serbian grapevine isolates of the M12 genotype have the same vmpA sequence, which is identical to isolate from Valle $\mathrm{d}$ 'Aosta. This could be an indication of introduction by planting material, but we find it strange that the same genotype has not induced epidemic outbreak in Italy while in north Serbia it became the dominant one with potential for competitive exclusion with regard to M51, as was experimentally evidenced for FD-C to outcompete FD-D [70]. This is why endemic emergence from alders or clematis still remains a possibility, especially because the same genotype of M12 was recently identified in Orienthus ishidae on Alnus glutinosa bordering vineyards of southern Swiss Alps [58], 
and in another invasive leafhopper Hishimonus hamatus in southern Switzerland on the edges and woods surrounding cultivated vineyards in 2017 [71]. This is an indication of the adaptation of the same genotype on a wider geographic area and the possibility of its simultaneous emergence in vineyard ecosystems. In addition, given the genetic relatedness between M12 and M51, which are SNP variants, clematis as a source plant and D. europaea as a natural primary vector from clematis to grapevine cannot be excluded. One thing we do know is that $O$. ishidae does not have any role in the M12 emergence in north Serbia since it is not present in this area [37].

Finally, we found direct evidence that at least two FDp endemic genotypes, M89 and M148 of the Map-FD2/VmpA-II clusters, have escaped from alders and propagated in grapevine-S. titanus pathosystem in Serbia (Vectotype II). The same is true for M155, which just has not yet been found in the alders, but according to $v m p A$, it is the genotype associated with European alders as a source plant. It is interesting that the $v m p A$ sequences of alder isolates from North Macedonia are fairly diversified and unique compared to those found in Serbian alders. It seems that either $v m p A$ also carries a geographic signal of diversity or that the vectors transferring FDp on alders in Serbia and North Macedonia are different. Overall, our findings confirmed the high complexity of the FDp ecological cycle in Serbia and provide evidence of unique, autochthonous Balkan epidemiology sourced endemically. The missing link in the broader epidemiological picture still represents the exact role of each of the insect vectors, especially in the light of sequence variations of $v m p A$ and $v m p B$ genes which have been linked to FDp transmission by different vectors [8]. This highlights the importance of analyzing variation in both vmp genes within insect vectors, which would hopefully interconnect all constituents of the FDp epidemiological cycle and identify the vector(s) responsible for current FDp epidemics as well as predict future ones. This is undoubtedly an objective that will be addressed in future research.

Supplementary Materials: The following supporting information can be downloaded at: https:/ / www.mdpi.com/article/10.3390/agronomy12020448/s1, Figure S1: Median-joining network inferred from 146 map genotypes of FDp and related strains previously identified across Europe and those identified in this study; Table S1: The list of previously identified and published map genotypes denoted in this study following nomenclature of Malembic-Maher et al. 2020; Table S2: The list of all localities of sampling sites for symptomatic FDp-infected Vitis vinifera in vineyards of Serbia, number of characterized isolates and number of associated map genotypes identified in this study; Table S3: The list of FDp-related isolates from natural reservoir or secondary host plants characterized on map and vmpA genes and their corresponding GenBank accession numbers sorted according to plant and geographic origin; Table S4: The list of FDp grapevine isolates characterized on map and vmpA genes and their corresponding GenBank accession numbers sorted according to the geographic origin.

Author Contributions: Conceptualization, O.K., T.C., I.T. and J.J.; methodology, O.K. and J.J.; validation, O.K.; formal analysis, O.K., T.C., S.M., M.J. and M.M.; investigation, O.K., T.C., S.M., M.J., M.M., I.T. and J.J.; data curation, O.K. and J.J.; visualization, O.K. and J.J.; supervision, I.T. and J.J.; writing-original draft preparation, O.K. and J.J.; writing—review and editing, O.K., T.C., S.M., M.J., M.M., I.T. and J.J. All authors have read and agreed to the published version of the manuscript.

Funding: This research was funded by Ministry of Education, Science and Technological Development of the Republic of Serbia, Contract No. 451-03-9/2021-14/200010.

Data Availability Statement: DNA sequences are available in the GenBank database, accession numbers are listed in Tables S3 and S4. All other relevant data are within the paper and its Supplementary Materials.

Acknowledgments: The authors are grateful to all the colleges from Agricultural Advisory and Professional Services of Serbia for their help in collecting symptomatic grapevine material, as well as to the Plant Protection Directorate of the Ministry of Agriculture, Forestry and Water Management of The Republic of Serbia for logistic support of the FDp surveillance programs. We acknowledge Andrea Kosovac for the technical support in laboratory diagnostics of phytoplasma presence in grapevine samples. The authors are grateful to Elisa Angelini (CREA Viticulture and Enology, Conegliano, Italy) for providing phytoplasma reference isolate of FD-D.

Conflicts of Interest: The authors declare no conflict of interest. 


\section{References}

1. Caudwell, A. Deux années d'étude sur la Flavescence dorée, nouvelle maladie grave de la vigne. Ann. Amélior. Plantes 1957, 4 , 359-363.

2. Constable, F.E. Phytoplasma epidemiology: Grapevines as a model. In Phytoplasmas: Genomes, Plant Hosts and Vectors; Weintraub, P.G., Jones, P., Eds.; CAB International: Wallingford, UK, 2010; pp. 188-212.

3. Chuche, J.; Thiéry, D. Biology and ecology of the Flavescence dorée vector Scaphoideus titanus: A review. Agron. Sustain. Dev. 2014, 34, 381-403. [CrossRef]

4. Jeger, M.; Bragard, C.; Caffier, D.; Candresse, T.; Chatzivassiliou, E.; Dehnen-Schmutz, K.; Gilioli, G.; Jaques Miret, J.A.; MacLeod, A.; Navajas Navarro, M.; et al. Risk to plant health of Flavescence doree for the EU territory. EFSA J. 2016, 14, 4603.

5. Tramontini, S.; Delbianco, A.; Vos, S. Pest survey card on Flavescence dorée phytoplasma and its vector Scaphoideus titanus. EFSA Support. Publ. 2020, 17, 1909E.

6. Jarausch, B.; Biancu, S.; Kugler, S.; Wetzel, T.; Baumann, M.; Winterhagen, P.; Jarausch, W.; Kortekamp, A.; Maixner, M. First Report of Flavescence Dorée-Related Phytoplasma in a Productive Vineyard in Germany. Plant Dis. 2021, 105, 3285. [CrossRef]

7. Arnaud, G.; Malembic-Maher, S.; Salar, P.; Bonnet, P.; Maixner, M.; Marcone, C.; Boudon-Padieu, E.; Foissac, X. Multilocus Sequence Typing Confirms the Close Genetic Interrelatedness of Three Distinct Flavescence dorée Phytoplasma Strain Clusters and Group 16SrV Phytoplasmas Infecting Grapevine and Alder in Europe. Appl. Environ. Microbiol. 2007, 73, 4001-4010. [CrossRef]

8. Malembic-Maher, S.; Desqué, D.; Khalil, D.; Salar, P.; Bergey, B.; Danet, J.L.; Duret, S.; Dubrana-Ourabah, M.P.; Beven, L.; Ember, I.; et al. When a Palearctic bacterium meets a Nearctic insect vector: Genetic and ecological insights into the emergence of the grapevine Flavescence dorée epidemics in Europe. PLoS Pathog. 2020, 16, e1007967. [CrossRef]

9. Casati, P.; Jermini, M.; Quaglino, F.; Corbani, G.; Schaerer, S.; Passera, A.; Bianco, P.A.; Rigamonti, I.E. New insights on Flavescence dorée phytoplasma ecology in the vineyard agro-ecosystem in southern Switzerland. Ann. Appl. Biol. 2017, 171, 37-51. [CrossRef]

10. de Sousa, E.; Casati, P.; Cardoso, F.; Baltazar, C.; Durante, G.; Quaglino, F.; Bianco, P.A. Flavescence dorée phytoplasma affecting grapevine (Vitis vinifera) newly reported in Portugal. Plant Pathol. 2010, 59, 398. [CrossRef]

11. Angelini, E.; Clair, D.; Borgo, M.; Bertaccini, A.; Boudon-Padieu, E. Flavescence dorée in France and Italy-Occurrence of closely related phytoplasma isolates and their near relationships to Palatinate grapevine yellows and an alder yellows phytoplasma. Vitis 2001, 40, 79-86.

12. Martini, M.; Botti, S.; Marcone, C.; Marzachı, C.; Casati, P.; Bianco, P.A.; Benedetti, R.; Bertaccini, A. Genetic variability among Flavescence dorée phytoplasmas from different origins in Italy and France. Mol. Cell. Probes 2002, 16, 197-208. [CrossRef] [PubMed]

13. Rossi, M.; Pegoraro, M.; Ripamonti, M.; Abbà, S.; Beal, D.; Giraudo, A.; Veratti, F.; Malembic-Maher, S.; Salar, P.; Bosco, D.; et al. Genetic Diversity of Flavescence Dorée Phytoplasmas at the Vineyard Scale. Appl. Environ. Microbiol. 2019, 85, e03123-18. [CrossRef] [PubMed]

14. Kriston, É.; Krizbai, L.; Juhász, E.; Melika, G. Status of grapevine "Flavescence dorée" in Hungary. Phytopathog. Mollicutes 2019, 9, 63-64. [CrossRef]

15. Plavec, J.; Budinšćak, Ž.; Križanac, I.; Škorić, D.; Foissac, X.; Šeruga Musić, M. Multilocus sequence typing reveals the presence of three distinct Flavescence dorée phytoplasma genetic clusters in Croatian vineyards. Plant Pathol. 2019, 68, 18-30. [CrossRef]

16. Mehle, N.; Rupar, M.; Seljak, G.; Ravnikar, M.; Dermastia, M. Molecular diversity of 'Flavescence dorée' phytoplasma strains in Slovenia. Bull. Insectology 2011, 64, S29-S30.

17. Reisenzein, H.; Steffek, R. First outbreaks of grapevine 'Flavescence dorée' in Austrian viticulture. Bull. Insectology 2011, 64, S223-S224.

18. Krnjajić, S.; Mitrović, M.; Cvrković, T.; Jović, J.; Petrović, A.; Forte, V.; Angelini, E.; Toševski, I. Occurrence and distribution of Scaphoideus titanus in multiple outbreaks of "flavescence dorée" in Serbia. Bull. Insectology 2007, 60, 197-198.

19. Holz, S.; Duduk, B.; Büttner, C.; Kube, M. Genetic variability of Alder yellows phytoplasma in Alnus glutinosa in its natural Spreewald habitat. For. Pathol. 2016, 46, 11-21. [CrossRef]

20. Krstić, O.; Cvrković, T.; Mitrović, M.; Radonjić, S.; Hrnčić, S.; Toševski, I.; Jović, J. Wolbachia infection in natural populations of Dictyophara europaea, an alternative vector of grapevine Flavescence dorée phytoplasma: Effects and interactions. Ann. Appl. Biol. 2018, 172, 47-64. [CrossRef]

21. Angelini, E.; Squizzato, F.; Lucchetta, G.; Borgo, M. Detection of a Phytoplasma Associated with Grapevine Flavescence dorée in Clematis vitalba. Eur. J. Plant Pathol. 2004, 110, 193-201. [CrossRef]

22. Filippin, L.; Jović, J.; Cvrković, T.; Forte, V.; Clair, D.; Toševski, I.; Boudon-Padieu, E.; Borgo, M.; Angelini, E. Molecular characteristics of phytoplasmas associated with Flavescence dorée in clematis and grapevine and preliminary results on the role of Dictyophara europaea as a vector. Plant Pathol. 2009, 58, 826-837. [CrossRef]

23. Valiunas, D.; Alminaite, A.; Staniulis, J.; Jomantiene, R.; Davis, R.E. First Report of Alder Yellows Phytoplasma in the Eastern Baltic Region. Plant Dis. 2001, 85, 1120. [CrossRef] [PubMed]

24. Cvrković, T.; Jović, J.; Mitrović, M.; Petrović, A.; Krnjajić, S.; Malembic-Maher, S.; Toševski, I. First report of alder yellows phytoplasma on common alder (Alnus glutinosa) in Serbia. Plant Pathol. 2008, 57, 773. [CrossRef]

25. Ember, I.; Acs, Z.; Salar, P.; Danet, J.L.; Foissac, X.; Koelber, M.; Malembic-Maher, S. Survey and genetic diversity of phytoplasmas from the 16SrV-C and -D subgroups in Hungary. Bull. Insectology 2011, 64, S33-S34.

26. Radonjić, S.; Hrnčić, S.; Krstić, O.; Cvrković, T.; Mitrović, M.; Jović, J.; Toševski, I. First Report of Alder Yellows Phytoplasma Infecting Common and Grey Alder (Alnus glutinosa and A. incana) in Montenegro. Plant Dis. 2013, 97, 686. [CrossRef] [PubMed] 
27. Atanasova, B.; Spasov, D.; Jakovljević, M.; Jović, J.; Krstić, O.; Mitrović, M.; Cvrković, T. First Report of Alder Yellows Phytoplasma Associated with Common Alder (Alnus glutinosa) in the Republic of Macedonia. Plant Dis. 2014, 98, 1268. [CrossRef] [PubMed]

28. Jurga, M.; Zwolińska, A. Artemisia vulgaris, a new host of $16 \mathrm{SrV}-\mathrm{C}$ phytoplasma related strains infecting black alder in Poland. J. Phytopathol. 2020, 168, 659-667. [CrossRef]

29. Reisenzein, H.; Strauss, G. Sporadic outbreaks of "Flavescence dorée" in Austrian vineyards and the role of Phlogottetix cyclops as a potential vector. Phytopathog. Mollicutes 2019, 9, 61-62. [CrossRef]

30. Seljak, G. Contribution to the knowledge of planthoppers and leafhoppers of Slovenia (Hemiptera: Auchenorrhyncha). Acta Entomol. Slov. 2004, 12, 189-216.

31. Mifsud, D.; Cocquempot, C.; Mühlethaler, R.; Wilson, M.; Streito, J.-C. Other Hemiptera Sternorrhyncha (Aleyrodidae, Phylloxeroidea, and Psylloidea) and Hemiptera Auchenorrhyncha Chapter 9.4. BioRisk 2020, 4, 511-552. [CrossRef]

32. EPPO. Orientus ishidae: A potential phytoplasma vector spreading in the EPPO region. EPPO Report. Serv. 2015, 5, 8-10.

33. Klejdysz, T.; Zwolińska, A.; Walczak, M.; Kobiałka, M. The first record of a potential pest Orientus ishidae (Matsumura, 1902) (Hemiptera: Cicadellidae) in Poland. J. Plant Prot. Res. 2017, 57, 107-112. [CrossRef]

34. Chireceanu, C.; Teodoru, A.; Gutue, M.; Dumitru, M.; Anastasiu, P. Two new invasive hemipteran species first recorded in Romania: Orientus ishidae (Matsumura 1902) (Cicadellidae) and Acanalonia conica (Say 1830) (Acanaloniidae). J. Entomol. Zool. Stud. 2017, 5, 824-830.

35. Gaffuri, F.; Sacchi, S.; Cavagna, B. First detection of the mosaic leafhopper, Orientus ishidae, in northern Italian vineyards infected by the flavescence dorée phytoplasma. New Dis. Rep. 2011, 24, 22. [CrossRef]

36. Lessio, F.; Picciau, L.; Gonella, E.; Tota, F.; Mandrioli, M.; Alma, A. The mosaic leafhopper Orientus ishidae: Host plants, spatial distribution, infectivity, and transmission of $16 \mathrm{SrV}$ phytoplasmas to vines. Bull. Insectology 2016, 69, $277-289$.

37. Cvrković, T.; Jović, J.; Jakovljević, M.; Krstić, O.; Marinković, S.; Mitrović, M.; Toševski, I. The "code red" for Balkan vineyards: Occurrence of Orientus ishidae (Matsumura, 1902) (Hemiptera: Cicadellidae) in Serbia. BioInvasions Rec. 2021, 10, 544-554. [CrossRef]

38. Filippin, L.; De Pra, V.; Zottini, M.; Borgo, M.; Angelini, E. Nucleotide sequencing of imp gene in phytoplasmas associated to 'Flavescence dorée' from Ailanthus altissima. Bull. Insectology 2011, 64, S49-S50.

39. Miladinović, Z.; Radulović, M.; Hrnčić, S.; Delić, D. Genetic variability of Scaphoideus titanus populations and a new host plant of 16SrV group phytoplasmas in Bosnia and Herzegovina. Phytopathog. Mollicutes 2019, 9, 111-112. [CrossRef]

40. Mehle, N.; Jakoš, N.; Mešl, M.; Miklavc, J.; Matko, B.; Rot, M.; Rus, A.F.; Brus, R.; Dermastia, M. Phytoplasmas associated with declining of hazelnut (Corylus avellana) in Slovenia. Eur. J. Plant Pathol. 2019, 155, 1117-1132. [CrossRef]

41. Duduk, B.; Ivanović, M.; Dukić, N.; Botti, S.; Bertaccini, A. First Report of an Elm Yellows Subgroup 16SrV-C Phytoplasma Infecting Grapevine in Serbia. Plant Dis. 2003, 87, 599. [CrossRef]

42. Magud, B.; Toševski, I. Scaphoideus titanus Ball. (Homoptera, Cicadellidae): A new pest in Serbia. Plant Dr. 2004, 32, 348-352.

43. Filippin, L.; Jović, J.; Forte, V.; Cvrković, T.; Toševski, I.; Borgo, M.; Angelini, E. Occurrence and diversity of phytoplasmas detected in clematis and their relationships with grapevine" Flavescence dorée" phytoplasmas. Bull. Insectology 2007, 60, 327-328.

44. Krstić, O.; Cvrković, T.; Mitrović, M.; Toševski, I.; Jović, J. Dictyophara europaea (Hemiptera: Fulgoromorpha: Dictyopharidae): Description of immatures, biology and host plant associations. Bull. Entomol. Res. 2016, 106, 395-405. [CrossRef] [PubMed]

45. Ivanišević, D.; Jakšić, D.; Korać, N. Vineyard Atlas: Census of Agriculture 2012 in the Republic of Serbia; Statistical Office of the Republic of Serbia: Belgrade, Serbia, 2015; pp. 1-413.

46. Statistical Office of the Republic of Serbia. Statistical Yearbook of the Republic of Serbia 2020; Statistical Office of the Republic of Serbia: Belgrade, Serbia, 2020; pp. 1-445. ISSN 0354-4206.

47. Hren, M.; Boben, J.; Rotter, A.; Kralj, P.; Gruden, K.; Ravnikar, M. Real-time PCR detection systems for Flavescence dorée and Bois noir phytoplasmas in grapevine: Comparison with conventional PCR detection and application in diagnostics. Plant Pathol. 2007, 56, 785-796. [CrossRef]

48. Pelletier, C.; Salar, P.; Gillet, J.; Cloquemin, G.; Very, P.; Foissac, X.; Malembic-Maher, S. Triplex real-time PCR assay for sensitive and simultaneous detection of grapevine phytoplasmas of the $16 \mathrm{SrV}$ and $16 \mathrm{SrXII}-\mathrm{A}$ groups with an endogenous analytical control. Vitis 2009, 48, 87-95.

49. Deng, S.; Hiruki, C. Amplification of 16S rRNA genes from culturable and nonculturable Mollicutes. J. Microbiol. Methods 1991, 14, 53-61. [CrossRef]

50. Smart, C.D.; Schneider, B.; Blomquist, C.L.; Guerra, L.J.; Harrison, N.A.; Ahrens, U.; Lorenz, K.H.; Seemüller, E.; Kirkpatrick, B.C. Phytoplasma-specific PCR primers based on sequences of the 16S-23S rRNA spacer region. Appl. Environ. Microbiol. 1996, 62, 2988-2993. [CrossRef]

51. Lee, I.M.; Gundersen, D.E.; Hammond, R.W.; Davis, R.E. Use of Mycoplasmalike Organism (MLO) Group-Specific Oligonucleotide Primers for Nested-PCR Assays to Detect Mixed-MLO Infections in a Single Host Plant. Phytopathology 1994, 84, 559-566. [CrossRef]

52. Gibb, K.S.; Padovan, A.C.; Mogen, B.D. Studies on Sweet Potato Little-Leaf Phytoplasma Detected in Sweet Potato and Other Plant Species Growing in Northern Australia. Phytopathology 1995, 85, 169-174. [CrossRef]

53. Padovan, A.C.; Gibb, K.S.; Bertaccini, A.; Vibio, M.; Bonfiglioli, R.E.; Magarey, P.A.; Sears, B.B. Molecular detection of the Australian grapevine yellows phytoplasma and comparison with grapevine yellows phytoplasmas from Italy. Aust. J. Grape Wine Res. 1995, 1, 25-31. [CrossRef] 
54. Jakovljević, M.; Jović, J.; Krstić, O.; Mitrović, M.; Marinković, S.; Toševski, I.; Cvrković, T. Diversity of phytoplasmas identified in the polyphagous leafhopper Euscelis incisus (Cicadellidae, Deltocephalinae) in Serbia: Pathogen inventory, epidemiological significance and vectoring potential. Eur. J. Plant Pathol. 2020, 156, 201-221. [CrossRef]

55. Mittelberger, C.; Obkircher, L.; Oberkofler, V.; Ianeselli, A.; Kerschbamer, C.; Gallmetzer, A.; Reyes-Dominguez, Y.; Letschka, T.; Janik, K. Development of a universal endogenous qPCR control for eukaryotic DNA samples. Plant Methods 2020, 16, 1-14. [CrossRef] [PubMed]

56. Jović, J.; Cvrković, T.; Mitrović, M.; Petrović, A.; Krstić, O.; Krnjajić, S.; Toševski, I. Multigene sequence data and genetic diversity among 'Candidatus Phytoplasma ulmi' strains infecting Ulmus spp. in Serbia. Plant Pathol. 2011, 60, 356-368. [CrossRef]

57. Tamura, K.; Peterson, D.; Peterson, N.; Stecher, G.; Nei, M.; Kumar, S. MEGA5: Molecular Evolutionary Genetics Analysis Using Maximum Likelihood, Evolutionary Distance, and Maximum Parsimony Methods. Mol. Biol. Evol. 2011, 28, $2731-2739$. [CrossRef] [PubMed]

58. Rizzoli, A.; Belgeri, E.; Jermini, M.; Conedera, M.; Filippin, L.; Angelini, E. Alnus glutinosa and Orientus ishidae (Matsumura, 1902) share phytoplasma genotypes linked to the 'Flavescence dorée' epidemics. J. Appl. Entomol. 2021, 145, 1015-1028. [CrossRef]

59. Posada, D.; Crandall, K.A. Selecting the Best-Fit Model of Nucleotide Substitution. Syst. Biol. 2001, 50, 580-601. [CrossRef]

60. Cassens, I.; Mardulyn, P.; Milinkovitch, M.C. Evaluating Intraspecific "Network" Construction Methods Using Simulated Sequence Data: Do Existing Algorithms Outperform the Global Maximum Parsimony Approach? Syst. Biol. 2005, 54, 363-372. [CrossRef]

61. Huson, D.H.; Bryant, D. Application of Phylogenetic Networks in Evolutionary Studies. Mol. Biol. Evol. 2006, 23, 254-267. [CrossRef]

62. Bandelt, H.J.; Forster, P.; Röhl, A. Median-joining networks for inferring intraspecific phylogenies. Mol. Biol. Evol. 1999, 16, 37-48. [CrossRef]

63. Kuzmanović, S.; Martini, M.; Ermacora, P.; Ferrini, F.; Starović, M.; Tošić, M.; Carraro, L.; Osler, R. Incidence and molecular characterization of Flavescence dorée and stolbur phytoplasmas in grapevine cultivars from different viticultural areas of Serbia. Vitis 2008, 47, 105-111.

64. Tanasijević, N. Constant and temporary members of leafhopper fauna in alfalfa in Yugoslavia. Plant Prot. 1964, 80, 379-388.

65. Tanasijević, N. A new contribution to the study of leafhopper fauna (Homoptera; Auchenorrhyncha). Plant Prot. 1966, 91-92, 205-212.

66. Tanasijević, N. The significance of leafhoppers in agriculture and forestry. Agrohemija 1967, 1-2, 73-78.

67. Cvrković, T.; Jović, J.; Mitrović, M.; Krstić, O.; Krnjajić, S.; Toševski, I. Potential new hemipteran vectors of stolbur phytoplasma in Serbian vineyards. Bull. Insectology 2011, 64, S129-S130.

68. Malembic-Maher, S.; Salar, P.; Filippin, L.; Carle, P.; Angelini, E.; Foissac, X. Genetic diversity of European phytoplasmas of the 16SrV taxonomic group and proposal of 'Candidatus Phytoplasma rubi'. Int. J. Syst. Evol. Microbiol. 2011, 61, 2129-2134. [CrossRef]

69. Arricau-Bouvery, N.; Duret, S.; Dubrana, M.P.; Batailler, B.; Desqué, D.; Béven, L.; Danet, J.L.; Monticone, M.; Bosco, D.; MalembicMaher, S.; et al. Variable Membrane Protein A of Flavescence Dorée Phytoplasma Binds the Midgut Perimicrovillar Membrane of Euscelidius variegatus and Promotes Adhesion to Its Epithelial Cells. Appl. Environ. Microbiol. 2018, 84, e02487-17. [CrossRef]

70. Rossi, M.; Vallino, M.; Galetto, L.; Marzachì, C. Competitive exclusion of Flavescence dorée phytoplasma strains in Catharanthus roseus plants. Plants 2020, 9, 1594. [CrossRef]

71. Belgeri, E.; Rizzoli, A.; Jermini, M.; Angelini, E.; Filippin, L.; Rigamonti, I.E. First report of Flavescence dorée phytoplasma identification and characterization in three species of leafhoppers. J. Plant Pathol. 2021. [CrossRef] 